\title{
The Expert Professor
}

\section{C.R. Young and the Toronto Building Code}

\author{
James Hull* \\ Introduction
}

In their insatiable thirst for funding, contemporary universities eagerly cast themselves as important agents of economic well-being. While the particular contexts and forms for this agency may be novel, such a role is not. Historians have long identified the significance of academic institutions to economic development at a number of levels. At the national level, the importance of the Technische Hochschulen and the Land Grant colleges to German and American leadership in the Second Industrial Revolution is well known while the significance of its system of higher education to a putative British industrial decline is more controversial (Oleson and Voss 1979, Sinclair 1980, Fox and Guagnini 1993, Dienel 1995, Edgerton 1996, Pfammatter 2000). At the subnational level, taking the example of Ontario, Canada, McKillop $(1994,149)$ observes that "an adjustment of universities to the conditions and requirements of industrial life was an essential ingredient in economic competition and development," with no university "untouched by the province's industrial revolution and the secular gospel of research." At the municipal level, in their study of three US cities, Kargon and Knowles $(2002,1)$ have seen local institutions of higher education "reacting quickly and creatively to unpredictable demands for expertise." It is this function of universities, or rather of their professoriates, as sources of local expertise which forms the focus of this paper.

Clarence Richard Young (1879-1964) was one of the most prominent and successful engineering educators in Canada during the first half of the twentieth century. Beginning as a lecturer at the University of Toronto's Faculty of Applied Science and Engineering (FASE) before World War One, his career culminated in his position as that Faculty's Dean during and after World War Two. Already enjoying a reputation among his peers as an authority on concrete construction and specification writing, Young first came into public prominence during a campaign to reform the City of Toronto's building code. As the city rebuilt from its disastrous 1904 Great Fire, a coalition of builders, engineers, architects and building material suppliers became increasingly dissatisfied with the City

\footnotetext{
* James Hull is an Associate Professor in the Irving K. Barber School of Arts and Sciences at the University of British Columbia's Okanagan campus. He is also an Associate Scholar of the Institute for the History and Philosophy of Science and Technology and a member of the Editorial Advisory Board of Left History. His research interests include the history of technical standards, engineering and technical education, and industrial research.
}

Spontaneous Generations 1:1 (2007). ISSN 1913-0465. University of Toronto 
Architect's office, in particular the provisions in the municipal Building By-Law regarding concrete. C. R. Young, publicly and behind the scenes, played a key role in coordinating this campaign and providing it with a solid technical basis. Eventually, a judicial inquiry into the operations of the Architect's office, relying heavily on the technical report of Professor Young, vindicated its critics. It was the first but not the last time in his career that Young was cast in the public role of the professor, part of the public service function of a university academic along with teaching and research. This is a function of the professoriate less studied by historians but one which was significant for academics' professional identities and personal success during the era of progressive reform. While the ideology of engineering transcended the local, it was as a local expert, representing local interests in the community in which his university was located, that Young was able to construct his identity as an expert professor

\section{Engineer and Educator}

Young was born at Salmon Point in Athol Township, Prince Edward County in 1879 of Loyalist stock (Engineering Authority 1964). After graduating from Picton High School, he attended the School of Practical Science, receiving his B.A.Sc. in 1905. In 1907, he received an appointment there as Lecturer in Structural Engineering at the renamed University of Toronto Faculty of Applied Science and Engineering (FASE). Young combined consultancy with an academic career in a pattern still common for engineering academics. In May 1909, he began an association with Frank Barber, a pioneer designer of concrete bridges in Ontario (Rose 1985). His reputation as an expert in this area quickly grew. An MIT student working on his graduation thesis wrote to Young asking for advice on the effect of frost on concrete and when the editor of the trade journal Contract Record received an inquiry about concrete hardening, he passed it along to Young (Shore 1912, Day 1915). In 1913, he became Assistant Professor in Applied Mechanics and advanced steadily through the professorial ranks, becoming Head of the Department of Civil Engineering in 1929 and Dean of the Faculty of Applied Science and Engineering from 1941 to 1949.

Young had a particular interest in the development and use of technical standards. As an active member of the Canadian Society of Civil Engineers' Toronto Branch, he participated in the process of technical standards formation. As well, he taught a $4^{\text {th }}$ year Contracts and Specifications course based on his own textbook (Young 1912). This reflected a profound on-going change not just in engineering practice but technology more broadly as standard specifications began to pervade the industrial order (Mallard 1998, Kindleberger 1983). While developing their own capability to administer standards, both public and private, bodies found themselves seeking expert assistance from university personnel. More broadly, the expertise of engineering faculties, along with their laboratory and testing facilities, made them a frequent source for assistance on matters 
great and small (Auger 2006). Most famously, Toronto Engineering Dean John Galbraith served as a member of the Royal Commission investigating the collapse of the Quebec Bridge in 1907 (Royal Commission 1908, Kranakis 2004).

Most instances, however, were more mundane and more local. A supplier to one of the T. Eaton Company's manufacturing arms used the result of a test performed at Toronto's engineering faculty to back up claims that their product met a strength standard (WEI 1915). In another instance, an inspector for the Ontario Department of Public Works examining a boiler at the Macdonald Institute in Guelph "found a heavy collection of a gummy substance.... Mr. Watson Bain, lecturer in Applied Science....analysed a sample...and pronounced it about 25\% oil" (Boiler Inspector 1906). In fact, when the Canadian Commission of Conservation sought information for a new building code, they learned that, unlike many other cities that relied on information from the United States, Toronto made use of the testing laboratories at the University of Toronto (Toronto Star, November 17, 1915). For example, the City drew upon FASE's testing laboratories for information on the strengths of materials and upon the expertise of engineering professor R.W. Angus for the administration of a test on the engine of a pumper for the Fire Department (Toronto 1926). And the Canadian Lumberman reported in its May 1907 edition that Toronto Professor J.M. Riddell carried out tests of Canadian and US softwood species at the request of a Canadian manufacturer to determine which met the specifications set by Toronto's City Architect. Later, when the President of the Montreal Lumber Association asked the Toronto City Architect to specify only Canadian lumber in city construction work, the two agreed that C.R. Young perform tests for fibre stresses to see to it that certain wood species met the requirements of the Building Code (Pearse 1914).

\section{Expert Engineer}

In the spring of 1909 the newly-founded Canadian Cement and Concrete Association (CCCA) met in London Ontario. A discussion of proposed standard specifications for concrete usage in construction was an early item of business (CCCA 1910). The Association's Vice President, Gustave Kahn, General Sales Manager of the Trussed Concrete Steel Company, addressed the delegates on "The Commercial Aspect of Reinforced Concrete in Canada." He singled out the city of Toronto for particular disapprobation after local brick interests had delayed the City Engineer's approval of concrete for a major trunk sewer. To carry forward work on standardization, the Association named a committee consisting of Kahn, C.R. Young, Peter Gillespie, lecturer in Applied Mechanics at the University of Toronto, and Montreal consulting engineer J.A. Jamieson. Young appears to have been the co-ordinator of the committee's work, no little part of which involved wrangling with Gustave Kahn who vigorously pressed his own ideas regarding concrete building regulations, ideas which reflected the practices of his own firm. Eventually, however, a consensus was reached (CCCA 1911). The Canadian Engineer editorialized favourably in its June 1911 edition, 
noting this was auspicious at a time when municipal building codes were under consideration for revision and use of concrete on the rise.

Little so concentrates the minds of civic politicians on the need for improved building codes as the experience of watching their city burn to the ground (Tebeau 2003). Not long after Toronto's Great Fire of April 1904 (Armstrong 1988), City Architect Robert McCallum had found himself defending his proposals for new building regulations against the objections of certain architects regarding the allowed thickness of walls and openings. When McCallum refused to issue a permit for a building on Temperance Street on the grounds that the concrete beams were not strong enough, the April 15, 1910 Toronto Globe reported a wrathful Gustave Kahn going before the Board of Control to argue that the design was satisfactory. In this case the Board decided to stick by McCallum but Kahn would have his revenge.

Later that year, the November 18, 1910 Globe reported that the Toronto Board of Education had received a letter from C.R. Young asking it to appoint representatives to a committee of engineers, architects, building contractors and others "who have been making a critical investigation of the Toronto building bylaw." By next spring such a committee was hard at work. The inquest into the collapse of a wall at the new Wm. Nielson factory in early May 1912, which killed two and injured fifteen, provided an open season on the Architect's office. As Slaton $(2001 a, 3)$ observes "[n]ew technologies brought a new understanding of what knowledge counted as authoritative on the building site, and what as retrograde and unreliable." Assistant Architect G.F.W. Price's insistence that a post-accident inspection showed workmanship and materials at the factory to have been sound was confirmed by Young's elder colleague C.H.C. Wright, University of Toronto Professor of Architecture and Drawing who gave expert testimony at the inquest. Neither a new building by-law in June nor amendments to it in August satisfied critics of the building code or the Architect's office. They added defects with the code to a growing bill of particulars being advanced against the City Architect. While changes in the code had removed what The Canadian Engineer in February 1914 called "a little of the undue severity... towards reinforced concrete construction" suggested revisions based on the Canadian Cement and Concrete Association standard had not been adopted. The Evening Telegram of August 16, 1912 reported that a number of local engineers, among them C.R. Young, helped draw the daggers. In a tone of magisterial objectivity, Young opined that an investigation into the operations of the Architect's department would be "desirable" and insisted that the objections being voiced against the by-laws and the Architect's office were "made from a scientific standpoint," some regulations being "unreasonable and unpractical."

Critics of the building code's construction requirements-and in practice advocates of the CCCA's alternative-gathered in the convivial surrounding of the Engineers' Club to plot strategy. Represented were the Canadian 
Manufacturers Association, the Board of Trade, the Canadian Society of Civil Engineers, the Ontario Association of Architects, the Toronto Society of Architects, the Builders' Exchange and the CCCA. This self-styled Citizens Committee, whose secretary was none other than Professor Young, received some accommodation: the Globe of February 21, 1913 reported that, against the wishes of the City Architect, the City Council's Property Committee voted 8-6 to change the building by-law.

Finally, in July 1913 McCallum was given a three-months leave of absencein effect, severance pay. In addition, Price was appointed acting City Architect until a permanent successor could be named. Toronto's Board of Control recommended Professor Wright but, in spite of support from the Mayor, the City Council rejected him and attempted instead to appoint Price to the permanent position. His supporters hailed Wright's technical and scientific qualifications while supporters of Price hailed him as a practical man. Charles Henry Challenor Wright had graduated from the School of Practical Science in 1888 and joined its faculty in 1890 after working in Boston for a construction company. In 1896 he assisted the University of Toronto's talented physics professor J.C. McLennan in replicating Roentgen's x-ray experiments. Although well-versed in materials science he in fact had no training as an architect and few links or friends among the local architectural profession (White 2000). As reported in the Toronto Star of January 5,1914 , in the course of the debate a variety of allegations and complaints about the functioning of the Architect's Office were made which led, early in 1914, to a judicial inquiry under Judge Herbert Denton, better known for his role in two notorious Toronto morality cases (Campbell 2000, Maynard 1997). To provide His Honour with expert technical opinion, Professor C.R. Young was commissioned to provide a report on the Building By-Law. Young was already known and respected by the city bureaucracy, at least outside of the City Architect's office. In 1913, Toronto City Commissioner R.C. Harris and the Assistant City Engineer had asked Young to report on and later to prepare structural designs for the proposed Bloor Street Viaduct.

In his report to Judge Denton, Young analysed the faults of the existing city building code's provisions finding them, "in many respects not in conformity with modern engineering practice," according to the Globe report on February 21, 1914. In an article in The Canadian Engineer published while the Denton inquiry was sitting, Young communicated his scathing criticism of the existing by-law as much too strict and conservative. He compared the Toronto by-law unfavourably to the standards of major railways, the Federal and Ontario governments, the Canadian Society of Civil Engineers and the municipal codes of various U.S. cities (Young 1914). After hearing from 170 witnesses, Judge Denton delivered his own lengthy report at the beginning of April (Toronto 1914a). He urged a complete reorganization of the City Architect's Department and praised C.R. Young's report which argued that, particularly in reinforced concrete, too much steel was required. This added materially to the cost of buildings.

Professor Young received \$253.75, roughly ten percent of his university 
salary at the time, in addition to Judge Denton's praise for his contribution in spending ten days examining and reporting on the building by-law (Toronto 1914b). Young also received the praise of his fellow engineers. C.M. Goodrich (1914) of the Canadian Bridge Company offered Young his "compliments on the clear way in which you have demonstrated the unnecessary severities of" the existing by-law. R.K. Palmer (1914), Engineer with the Hamilton Bridge Works, allowed that he had "often noticed the inconsistencies arising in these building by-laws," blaming "ignorance [and] local politics." Engineers enjoyed contrasting ignorance and local politics with the supposed rationality and universality of their science-based technology. This was an ideology which they absorbed in the classroom and laboratory along with their training in strengths of materials (Shenhav 1999). In fact, however, quantification, standardization and precision represent a social programme not merely a technical one. As Slaton (2001b) has pointed out standards at the work site are part of engineers' exercise of "intellectual authority" there, going hand in hand with their managerial authority.

The other major item of business was the appointment of a new City Architect. On May 4, 1914, Council discussed the matter for $2 \frac{1}{2}$ hours. In the running were Young's fellow expert professor C.H.C. Wright, insider G.F.W. Price and a new contender, Willis Worth Pearse. A graduate of Toronto's Jarvis Collegiate, Pearse (b. 1872) had taken his B.Sc. and then C.E. through Cooper Union and became an Associate Member of the American Society of Civil Engineers. Vice President and chief architect with the John Radley Company in New York City, Pearse was eager to return to his native city where his grandfather had been a successful building contractor (Middleton 1923). In spite of the Denton report, Price still had his supporters including Alderman Sam McBride. Unimpressed, at best, by the academic credentials of Pearse and Wright, McBride insisted that the city needed "more practice and less theory." Perhaps coincidentally, Wright, in his course on Building Materials at the Faculty of Applied Science, had that year placed a special emphasis on concrete, asking three questions about that material on the short final examination. Controller James Simpson stated that if appointed, Pearse "intended to supplement the building code of the city by giving the formulas embodied in it. They would be a great help to builders" (Telegraph, May 5, 1914) Pearse and the builders won. The former was soon at work on a new Code which, in following along the lines of Young's recommendations, would "lessen the steel work and reduce the cost of the buildings" (Star, February 17, 1915).

\section{Conclusions}

Young's report to the Denton inquiry certainly enhanced his reputation as a source of impartial expert opinion; during his long career Young would often act as an expert witness and arbitrator. As an engineering educator, Young became a 
strikingly thoughtful and broadly-visioned man. As Dean of the Faculty of Applied Science and Engineering, he insisted (as had Vitruvius two millennia earlier) on a strong humanities component to students' programmes (White 2000). In their introduction to a recent volume of essays on the Canadian professoriate, Stortz and Panayotidis $(2006,6)$ have commented on how attention to the history of that social group can more widely inform our understanding of "the relationship between intellectuals and society, economics, politics, communities, and cultures." A close examination of this particular incident enables us to learn much about the position and role of the professoriate in early twentieth century Canada. Engineering and science professors were part of what Kargon and Knowles (2002) have termed "an emerging economy of certified 'experts'." Both the architecture and engineering professions had endured difficult transitions, from "art to practice" in the case of the former and "shop culture to school culture" in the case of the latter (Calvert 1967, Crossman 1987, Pfammatter 2000). In both cases debates over the nature of education in professional formation had been key. Young integrated his personal, professional, technical and pedagogical concerns into a package which gained public recognition as a source of, seemingly, disinterested expertise. He contributed significantly to the growth and development of the engineering profession and of engineering education in Canada while helping maintain its links with the business world during an era of industrial change. Drawing on the engineering profession's ideals of a science-based rationality Young used his position as professor and expert to help shape his community physically and politically while also shaping a lucrative and successful career for himself, one resting on an identity as an expert professor.

JAMES HULL

University of British Columbia

james.hull@ubc.ca

\section{References}

ASTM see American Society for Testing and Materials

American Society for Testing and Materials. 1999. What is ASTM? New York: ASTM.

Armstrong, Frederick. 1988. A city in the making. Toronto: Dundurn Press.

Auger, Jean-François. 2006. L'université au service de l'industrie: la vente de service de laboratoire en génie au Canada, 1895-1939. In Transformations des universities $d u X I I I^{e}$ au XX siècle, ed. Yves Gingras and Lyse Roy. Montréal: Presses de l'université du Québec à Montréal.

Boiler Inspector. 1906. Report to F.R. Heakes dated 23 February. Boiler Inspection

Reports, RG15-81, Department of Public Works. Archives of Ontario. 
Calvert, Monte A. 1967. The mechanical engineer in America, 1830-1910. Baltimore: Johns Hopkins University Press.

Campell, Lyndsay. 2000. A slub in the cloth. Canadian journal of law and society 15: $187-220$.

Canadian Cement and Concrete Association. 1910 Annual Report and Proceedings of the Canadian Cement and Concrete Association. n.p

Canadian Cement and Concrete Association. 1911 Canadian Cement and Concrete Association Proceedings. n.p.

CCCA see Canadian Cement and Concrete Association

Crossman, Kelly. 1987. Architecture in transition: From art to practice, 18851906. Montreal \& Kingston: McGill-Queen's University Press.

Day, G.W.N. 1915. Letter to C.R. Young dated 13 January. C.R. Young Correspondence.

A66-0011, Department of Civil Engineering Papers, University of Toronto Archives.

Dienel, Hang-Liudger. 1995. Ingenieurs zwischen Hochschule und Industrie. Göttinger: Vandenhoek \& Ruprecht.

Edgerton, David. 1996. Science, technology and the British industrial 'decline' 1870-1970. Cambridge: Cambridge University Press.

Engineering authority at $U$ of T for 42 Years. 1964. Globe and Mail, 4 April.

Fox, Robert and Anna Guagnini. 1993. Education, technology and industrial performance in Europe, 1850-1939. Cambridge: Cambridge University Press.

Goodrich, C.M. 1914. Letter to C.R. Young dated 26 May C.R. Young Correspondence.

A66-0011, Department of Civil Engineering Papers, University of Toronto Archives.

Kargon, Robert H. and Scott G. Knowles. 2002. Knowledge for use: Science, higher learning, and America's new industrial heartland, 1880-1915. Annals of Science 59: 1-20.

Kindleberger, Charles. 1983. Standards as public, collective and private goods. Kyklos 36: 377-96.

Kranakis, Eda. Fixing the blame: Organizational culture and the Quebec Bridge collapse. Technology and culture 45: 487-518.

Mallard, Alexandre. 1998. Compare, standardize and settle agreement. Social studies sf Science 28: 571-601.

Maynard, Steven. 1997. Horrible temptations. Canadian historical review 78: 191-235.

McKillop, A.B. 1994. Matters of Mind. Toronto: University of Toronto Press.

Middleton, Edger J. 1923. The Municipality of Toronto. Toronto: Dominion Publishing Company.

Oleson, Alexandra and John Voss. 1979. The organization of knowledge in modern America 1860-1920. Baltimore: Johns Hopkins University Press. 
Palmer, R.K. 1914. Letter to C.R. Young dated 6 May, C.R. Young Correspondence.

A66-0011, Department of Civil Engineering Papers, University of Toronto Archives.

Pearse, W.W. 1914. Letter to C.R. Young dated 24 June C.R. Young Correspondence.

A66-0011, Department of Civil Engineering Papers, University of Toronto Archives.

Pfammater, Ulrich. 2000. The Making of the modern architect and engineer. Basel, Birkhäus.

Rose, Phyllis Esther. 1985. Frank Barber and his bridges. Master's thesis. University of Toronto

Royal Commission on Collapse of Quebec Bridge. 1908. Quebec Bridge inquiry report. Ottawa: King's Printer.

Shenhav, Yehouda. 1999. Manufacturing rationality. Oxford: Oxford University Press.

Shore, J.D. 1912 Letter to C.R. Young dated 10 February C.R. Young Correspondence.

A66-0011, Department of Civil Engineering Papers, University of Toronto Archives.

Sinclair, Bruce. 1980. A Centennial history of the American Society of Mechanical Engineers 1880-1980. Toronto: University of Toronto Press.

Slaton, Amy. 2001a. Reinforced concrete and the modernization of American building, 1900-1930. Baltimore: Johns Hopkins.

Slaton, Amy .2001b. 'As Near as Practicable': Precision, ambiguity, and the social features of industrial quality control. Technology and culture 42: 51-80.

Stortz, Paul and Lisa E. Panayotidis, eds. 2006. Historical identities: The professoriate in Canada. Toronto: University of Toronto Press.

Tebeau, Mark. 2003. Eating smoke: Fire in urban America 1800-1950. Baltimore: Johns Hopkins University Press.

Toronto. 1914a. Council Minutes 6 April, item 380.

Toronto. 1914b. Council Minutes Appendix A Board of Control Report \#11.

Toronto. 1926. Council Minutes Appendix A 1321-23 Fire Department to Mayor and Board of Control.

Young, C.R. 1912. Principals of specification and agreement writing. Toronto: Canadian Engineer.

Young, C.R. 1914. The structural requirements of the Toronto building by-law of 1913. The Canadian Engineer 26 February: 383-88.

WEI. 1915. Letter to S. Wickett dated 27 November. T Eaton Papers, Manufacturing.

Head Office F229 Series 156 Box 1.Archives of Ontario.

White, Richard. 2000. The Skule story: The University of Toronto Faculty of Applied Science and Engineering, 1873-2000. Toronto: University of Toronto Press. 